\title{
Developing a Model of First Year Student Satisfaction in a Studio-based Teaching Environment
}

\author{
Angela Carbone and Judy Sheard \\ Monash University, Melbourne, Australia
}

\section{Angela.Carbone@sims.monash.edu.au Judy.Sheard@csse.monash.edu.au}

\section{Executive Summary}

This paper evaluates a studio-based teaching model in a core first year subject of a traditionally delivered IT degree at an Australian university. It reports on first year students' reactions to four aspects of the studio-based teaching and learning environment: the physical learning space, IT tools and infrastructure, teaching philosophy, and portfolio assessment. Data was obtained through online Web-based surveys, issued mid-year and at the end of the year. The surveys were used to construct a model of students' satisfaction, including what influences the students' use of the new environment and their perceptions of its value to their learning. Re sults revealed various factors that influence the students' satisfaction of studio-based teaching. Students found the studio precinct an inviting and comfortable place to learn despite some frustrations with IT-related problems. Students' comments indicate the teaching environment facilitated collaboration, and by the end of the year they began to see the course as being better integrated. An unexpected finding of this study was the evidence of students developing metacognitive skills via the portfolio component of the student assessment.

Keywords : evaluation, studio-based teaching and learning, portfolio assessment.

\section{Introduction}

An innovative teaching and learning environment was established in 2000 in the School of Information Management and Systems at Monash University, Australia. Taking inspiration from the Bauhaus School of Design, a studio model was incorporated into a core subject in all year levels of the Bachelor of Information Management and Systems (BIMS). The studio model is a radical shift from the lecture/tutorial teaching environment typically found in a tertiary institution. It has meant the construction of a new teaching space, provision of a supporting IT infrastructure and the development of a curriculum integrated within and across all year levels.

The initial cost of building, furnishing and equipping the studio was funded by a grant (Carbone et al., 1999). The ongoing cost in terms of maintenance and technical support is equivalent to a traditional teaching environment. However, the high staff-student ratio, particularly at the lecturer level, has meant

Material published as part of this journal, either on-line or in print, is copyrighted by the publisher of the Journal of Information Technology Education. Permission to make digital or paper copy of part or all of these works for personal or classroom use is granted without fee provided that the copies are not made or distributed for profit or commercial advantage AND that copies 1) bear this notice in full and 2) give the full citation on the first page. It is permissible to abstract these works so long as credit is given. To copy in all other cases or to republish or to post on a server or to redistribute to lists requires specific permission and payment of a fee. Contact Editor@JITE.org to request redistribution permission. that the cost of running a studio subject is approximately three times more than teaching with the traditional approach.

This paper compares first year students' reactions, at mid-year and at the end of the year, in respect to four aspects of the studio model: the layout of the physical teaching space, the integrated curriculum, the IT infrastructure, and use of portfolio assessment. It also reports on students' reactions 
to the studio in comparison to the traditional teaching environments they experience in their other subjects. Data was obtained through survey questionnaires. Results are used to inform a discussion of the issue of appropriate teaching and learning environments for first year IT students. This paper extends the research that examined the students' reactions to the studio in semester 1 of 2001, (Carbone and Sheard 2002). Other research has compared students' reactions across the three year levels of the undergraduate BIMS degree (Carbone et al., 2002a; Carbone et al., 2002b).

\section{Background}

The studio model has been described in (Arnott \& Atchison, 1997; Carbone et al., 2000). Excerpts from the Carbone et al. paper, (2000), that describe the four aspects of the SIMS studio and its foundational influences are included below to enable the reader to gain a full understanding of the context of the research.

\section{The BIMS Undergraduate Degree Program}

The Bachelor of Information Management and Systems (BIMS), at Monash University, Australia, is a three-year IT degree with a strong practical focus. It aims to prepare students for careers in information systems and information management. Central to the BIMS program is a compulsory (core) year long studio subject in each year of the course. Other core subjects include information systems, information management, systems analysis and design, project management, the Internet, and multimedia. In addition to the core subjects, students can select elective subjects from a wide range of disciplines that are usually taught in a traditional setting.

\section{The Bauhaus Influence}

The studio-based teaching and learning approach adopted for use in the BIMS program is based on the Bauhaus School of Design's model for teaching and learning. The Bauhaus, developed in Germany in the early 1900s, was an innovative art school whose basic ideologies started a move towards the better integration of art and technology for the mutual benefit of both (Flores, 2000). The Bauhaus set out to create a "consulting art center for industry and the trades" (Bayer, 1975). The influences of the Bauhaus are widespread and varied, and the educational concepts upon which the Bauhaus philosophy was based appealed to the BIMS teaching and learning development team.

The Bauhaus school had three aims: the first was to "rescue all of the arts from the isolation in which each then found itself" (Whitford, 1992) in order to encourage the individual artisans and craftsmen to work cooperatively and combine all of their skills. Secondly, the school set out to elevate the status of crafts and every day objects such as chairs, lamps, teapots, etc., to the same level enjoyed by the fine arts, painting, sculpting, etc. The third aim was to establish contact with the leaders of industry and craft in an attempt to eventually gain independence from government support by selling designs to industry.

\section{A Bauhaus Inspired Studio-based Teaching and Learning in an IT Curriculum}

The Bauhaus inspired the studio-based teaching and learning model, a radical change from the traditional teaching model, which is based in lecture theatre, tutorial room, and laboratory environments. The BIMS teaching staff instigated the adaption of the Bauhaus model to the BIMS program and the program has been enhanced by the contribution of educational developers at several Australian universities (Jamieson et al., 2000). The IT studio model centers on a new design of the physical teaching and learning space. The teaching and learning philosophy of the IT studio model is based upon an integrated curriculum and a collaborative learning environment, which bring many advantages to the students 
(Shoemaker, 1989). The IT infrastructure was designed to support students both on and off campus and assist in their group work. The portfolio assessment was intended to provide students with an element of creative freedom, to inspire inno vation and enable them to control their own learning (Federico, 1999). The four aspects of the studio model in the IT curriculum are elaborated below.

\section{The physical studio environment}

The studio precinct employs an alternative space configuration; it comprises two studios (Studio 1 and Studio 2), a Studio Café, and a meeting room. A floor plan of the studio maybe found at http://www.sims.monash.edu.au/studios/bis/physical.htm

Studio 1 is the space where IT literacy and didactic teaching occurs. It is the foundation space where basic critical skills can be acquired and developed. Students commonly work in groups of three, share ideas with groups in close proximity to them, or less frequently, work individually. Studio 2 is a space for more intense teamwork. A large conference-type table in the centre of the room is used for discussions of up to 25 students, and smaller 'D' shaped tables on the room's perimeter are used for groups of up to five students.

The Internet café is an informal meeting place and social centre of the BIMS studio precinct, and its design reflects this. The café is also a space where students and staff can go for relief from intensive studio activity. As the studio precinct is accessible twenty-four hours a day, seven days a week, the café is equipped with a kitchenette. The meeting room is designed as a professional space with high quality furniture and facilities. It is used for consultations, studio group meetings, student meetings, presentations, and ad hoc purposes.

\section{Integrated curriculum}

The teaching and learning philosophy of the BIMS program has two main foci: one that is concerned with integrating the curriculum across core subjects, and the other to create a collaborative working environment. A team of teaching staff, comprising a studio manager, studio year leaders and three to four studio academics, devises the integrated curriculum. The studio year leader works closely with the studio academics that teach in the other core subjects, to direct and oversee the integration of subject material across a particular year level. The studio manager liaises with the studio year leaders to produce a fully integrated curriculum over the whole program. An integrated curriculum, which requires the students to use content and skills from other core subjects, brings many advantages to the students (Shoemaker, 1989).

The physical layout of the studio was designed to provide a collaborative working environment. For most activities students are expected to work together in small groups on projects designed to enhance their skills. As part of the collaboration process, students are expected to contribute to the learning of their group, manage the scheduling of their own studio group activities, and negotiate with other teams when working on projects.

\section{IT infrastructure}

One of the basic ideologies behind the BIMS studio-approach is to simulate professional practice. With this in mind, the IT infrastructure was designed to support the students whether they are within the physical space or away from it. Students are encouraged to use the communication technologies and IT tools (on-line threaded discussion groups, computer aided dynamic assessment and learning, electronically available notes, multimedia simulations, synchronous communications) to assist them to collaborate with their peers and communicate with tutors and academics. Each studio is fully networked and equipped with desktop computers, with approximately one computer for every three students. There are 
also a number of peripheral devices available for loan to students, including digital cameras, desktop video conferencing cameras, Windows notebooks, iBooks, and USB floppy drives. Full details of the IT infrastructure for the studio based degree are covered in (Lynch, 2001).

\section{Portfolio assessment}

As a major component of their assessment in the studio subject each student is required to develop a portfolio of his or her work. The concept of a portfolio is described extensively in the literature. Paulson, Paulson and Meyer (1991) describe a portfolio as "a purposeful collection of student work that exhibits the student's efforts, progress, and achievements in one or more areas of the curriculum," and "a collaborative, self-reflective collection of student work generated during the process of instruction."

In a portfolio, the student presents and explains his or her best "learning treasures" against the subject's objectives. Portfolios are intended to demonstrate the students' efforts, progress and achievements in a given area. They are usually self-reflected and autonomous (Moran \& Robinson, 1994; Anderson \& Bachor, 1998). For example, this could be in the form of a reflective journal or a student's own application developed to highlight their mastering of a programming language taught in the studio.

In the first year studio subject, $50 \%$ of the final marks are devoted to portfolio items prescribed by the academics, whilst $30 \%$ of the marks are allocated for portfolio items selected by the students. Students are expected to include at least four items on their own initiative. It is made explicit to the students that they are to be creative in deciding what to include in their portfolios and that these items should reflect their learning and development on the field. The remaining $20 \%$ is tested via a formal examination.

\section{Research Design}

\section{Research Method}

This study investigated students' satisfaction with learning in the new IT studio teaching and learning environment. The students were enrolled in IMS1000 First Year Studio in the BIMS program. This group of students was chosen because the purpose of this study was to evaluate an appropriate learning environment for first year students. Although these students were new to the university teaching environment, they were able to compare the studio with the traditional teaching environment they were experiencing in other subjects in their course. The students were surveyed during the last week of semester 1 , and again in the last week of semester 2, when all four components of the studio subject (programming, tools and technology, information management, and information systems) had been presented to them and they had completed their mandatory portfolio work. All the students were asked to complete an online questionnaire that was designed and developed by a research team in SIMS (Carbone et al., 2001); participation in the survey was voluntary.

\section{Data Collection and Analysis}

The questionnaire asked students to rate the learning environment, the facilities available to them, the subject content, assessment method, and the level of satisfaction on 5-point Likert scales. Demographic data were gathered to help establish a profile of the students and enable comparisons to be made between responses on the basis of gender and the background of the students. The responses of students were analysed using a variety of statistical tests.

The students were also given the opportunity to provide open-ended comments about all aspects of the studio environment. At the end of the questionnaire provision was made for students to add additional 
comments or make recommendations. Themes that emerged in the open-ended questions were categorized according to the foci of the study.

\section{Results}

\section{Student Profiles}

At mid-year, 132 of the 140 students enrolled in IMS1000 First Year Studio, completed the survey. Demographic data in terms of gender, international status, degree of study and age were as follows: 70 Males and 62 Females, 36 international students and 96 local students. Most students (124) were enrolled in the BIMS program; however, eight students were enrolled in a double degree program. The majority of students (79\%) were between the ages of 18 and 21.

At the end of the year, 115 students were enrolled in IMS1000 with only 61 completing the survey. This is a lower response rate than in midyear because computer problems prevented one studio group from submitting their survey responses. Demographic data of the students that completed the survey in terms of gender, international status, degree and age were as follows: 30 Males and 31 Females, 19 international students and 42 local students. Of those students that completed the survey most (54) were enrolled in the BIMS program however seven students were enrolled in a double degree. The majority of students $(76 \%)$ were between the ages of 18 and 21 .

\section{The Teaching and Learning Environment}

\section{The physical space}

The means and standard deviations of the students' ratings of the physical spaces (Studio 1, Studio 2, Café and the meeting room) in terms of a place for learning in semesters 1 and 2 are shown in Table 1. A 5-point Likert scale was used, where 1 indicated very poor and 5 indicated very good.

The low standard deviations indicate small variations in the students' opinion with regard to the learning

\begin{tabular}{lllll}
\hline & \multicolumn{2}{c}{ Jun 2001 } & \multicolumn{2}{l}{ Oct 2001 } \\
Rate the following: & Mean & SD & Mean & SD \\
\hline Studio 1 as a learning space & 4.35 & 0.92 & 4.18 & 1.02 \\
Studio 2 as a learning space & 4.26 & 0.88 & 4.08 & 1.05 \\
Cafe as a learning space & 3.99 & 0.97 & 3.90 & 1.06 \\
Studio meeting room as a learning space & 4.03 & 0.91 & 4.20 & 0.95 \\
Studio 1 in terms of comfort level & 4.47 & 0.88 & 4.44 & 0.67 \\
Studio 2 in terms of comfort level & 4.43 & 0.76 & 4.31 & 0.83 \\
Cafe in terms of comfort level & 4.13 & 0.99 & 4.11 & 1.02 \\
Studio meeting room in terms of comfort level & 4.03 & 0.93 & 4.08 & 1.04 \\
\hline
\end{tabular}

\section{Table 1: Students' ratings of the learning environment}


environment. Differences between student responses in semester 1 and 2 were tested using independent groups t-tests and were found to be non-significant.

\section{IT tools and infrastructure}

\begin{tabular}{lllll}
\hline \multirow{2}{*}{ How often did you use? } & \multicolumn{2}{c}{ Jun 2001 } & \multicolumn{2}{c}{ Oct 2001 } \\
& Mean & SD & Mean & SD \\
\hline Loan equipment - iBook, zip drives, digital camera & 1.78 & 1.15 & 1.92 & 1.22 \\
Radio frequency network & 1.68 & 1.09 & 1.57 & 1.12 \\
Web access to studio software & 3.72 & 1.51 & 3.89 & 1.38 \\
Subject Website & 4.58 & 0.80 & 4.93 & 0.31 \\
Email & 4.33 & 1.15 & 4.48 & 1.19 \\
Subject online discussion area & 2.55 & 1.13 & 2.28 & 1.00 \\
\hline
\end{tabular}

\section{Table 2: Students' ratings of IT tools and infrastructure}

The means and standard deviations of the students' ratings of how often they borrowed the IT equipment in semesters 1 and 2 are shown in Table 2. A 5-point Likert scale was used, where 1 indicated not at all and 5 indicated frequently.

Differences between semester 1 and 2 student responses were tested using independent groups t-tests. By semester 2 students' access to the subject's website was significantly more frequent $(M=4.93$, $s d=0.31)$ compared to semester $1(M=4.58, s d=0.80, t(61)=0, p<0.05)$. Although the course was not a web-delivered course, results show that students regularly accessed the website to download support materials, lecture notes, studio exercises and a trial online assessment.

\section{Portfolio Assessment}

\begin{tabular}{|c|c|c|c|c|}
\hline \multirow[b]{2}{*}{ Rate the difficulty in: } & \multicolumn{2}{|c|}{ Jun 2001} & \multicolumn{2}{|c|}{ Oct 2001} \\
\hline & Mean & SD & Mean & SD \\
\hline $\begin{array}{l}\text { Deciding which items to submit for the self-selected } \\
\text { portfolio }\end{array}$ & 2.59 & 0.98 & 3.05 & 0.95 \\
\hline Completing the mandatory portfolio requirements & 2.66 & 0.87 & 2.83 & 0.85 \\
\hline $\begin{array}{l}\text { Representing in my portfolio the level of my skills } \\
\text { and knowledge }\end{array}$ & 3.24 & 1.13 & 3.39 & 1.07 \\
\hline Organising the portfolio & 2.74 & 0.94 & 3.08 & 0.67 \\
\hline
\end{tabular}

Table 3 Students' responses to portfolio assessment

Table 3 contains the means and standard deviations of the students' ratings of aspects of the portfolio assessment at the end of semester 1 and semester 2. A 5-point Likert scale was used, where 1 indicated very difficult and 5 indicated very easy.

Independent group t-tests were used to determine any differences in the means in student responses between semester 1 and semester 2. Two significant differences were found. By semester 2, students found 
it easier to decide what items to submit in their portfolios $(M=3.05, s d=0.95)$ compared to semester 1 $(M=2.59, s d=0.98 ; t(61)=-3.1, p<0.05)$, and students found it much easier to organise their portfolios in semester $2(M=3.08, s d=0.67)$ than in semester $1(M=2.74, s d=0.94, t(61)=-2.87, p<0.05)$.

\section{Teaching and Learning Philosophy}

The means and standard deviations of the students' ratings of components of the teaching and learning method in semesters 1 and 2 are shown in Table 4. A 5-point Likert scale was used, where 1 indicated not at all and 5 indicated frequently.

Differences between semester 1 and semester 2 student responses were tested using independent groups t-tests. The following significant differences were found:

- students were collaborating within the group more frequently in semester $1(M=4.17, s d=0.82)$ compared to semester $2(M=3.90, s d=0.89, t(61)=2.10, p<0.05)$.

\begin{tabular}{|c|c|c|c|c|}
\hline \multirow[b]{2}{*}{ Rate the following: } & \multicolumn{2}{|c|}{ Jun 2001} & \multicolumn{2}{|c|}{ Oct 2001} \\
\hline & Mean & SD & Mean & SD \\
\hline I used content and skills from other core subjects & 3.65 & 1.01 & 3.68 & 0.94 \\
\hline Group work contributed to my learning & 3.95 & 0.93 & 4.02 & 0.93 \\
\hline $\begin{array}{l}\text { I collaborated with my group to complete the activi- } \\
\text { ties }\end{array}$ & 4.17 & 0.82 & 3.90 & 0.89 \\
\hline Access to the studio spaces was available & 4.01 & 0.95 & 3.84 & 0.92 \\
\hline I received sufficient assistance from the teaching staff & 3.60 & 1.05 & 3.96 & 0.82 \\
\hline $\begin{array}{l}\text { I was required to manage my time when undertaking } \\
\text { the studio activities }\end{array}$ & 3.92 & 0.87 & 4.12 & 0.80 \\
\hline $\begin{array}{l}\text { I was required to negotiate involvement with team } \\
\text { members when working on activities }\end{array}$ & 4.16 & 0.88 & 4.02 & 0.91 \\
\hline $\begin{array}{l}\text { The level at which the studio activities developed my } \\
\text { own skills and knowledge }\end{array}$ & 3.77 & 0.96 & 4.17 & 0.87 \\
\hline $\begin{array}{l}\text { The level which the seminar session prepares you for } \\
\text { your studio work }\end{array}$ & 3.52 & 1.15 & 3.57 & 1.04 \\
\hline Multiple teaching staff in IMS1000 was valuable & 3.50 & 1.16 & 3.85 & 1.16 \\
\hline
\end{tabular}

Table 4: Students' ratings of the teaching and learning approach

- students were seeking considerably more assistance from the teaching staff in semester $2(M=3.96$, $\mathrm{sd}=0.82)$ than semester $1(M=3.60, s d=1.05, t(61)=2.39, p<0.05)$.

- $\quad$ students felt the studio activities in semester $2(M=4.17, s d=0.87)$ were better at developing their skills and knowledge than those provided in semester $1(M=3.77, \mathrm{~s} d=0.96, t(61)=2.41, p<0.05)$.

\section{Level of Satisfaction}

The means and standard deviations of the students' ratings of the level of satisfaction of the studio at the end of semester 1 and semester 2 are shown in Table 5. A 5-point Likert scale was used, where 1 indicated very low/strongly disagree and 5 indicated very high/strongly agree. 
Independent group t-tests were used to determine any differences in the means obtained for the satisfaction measures during semester 1 and 2. A significant difference was found with students showing greater preference to learning in the studio environment in semester $2(M=4.18, s d=0.99)$ than compared with semester $1(M=3.87, s d=1.04, t(61)=-1.99, p<0.05)$.

Pearson's Correlation coefficients were calculated to measure the strength of relationship between the satisfaction measures. An interesting finding in semester 2 was that the ease of which students felt they were able to represent their level of skills and knowledge in their portfolio was highly correlated with the students' level of satisfaction with the subject's content $(r=0.59)$ and the students' level of satisfaction with the overall course $(r=0.63)$. Other strong relationships were shown which were not unexpected. A high correlation was found between the students' level of satisfaction with the course and their level of satisfaction with the subject ( $r=0.65$ ), and whether students would recommend the course to others was highly correlated with their level of satisfaction with the subject $(r=0.57)$ and the course $(r=0.60)$.

\section{Impact on Student Satisfaction}

The impact of the various aspects of the Studio Model were investigated using a regression on the students' level of satisfaction with the variables in Tables 3 and 4 which had correlation coefficients greater than 0.3:

- In semester 1 , the level of satisfaction with the subject was regressed with teaching and learning variables and produced an $R^{2}$ value of 0.59 and a significant ANOVA for residuals $(F=11.94$ $(12,101), p<0.05)$. Significant results were produced by how well the studio activities developed their skills and knowledge $(b=0.28, t=3.32, p<0.05)$, how valuable they found multiple teaching staff $(b=0.32, t=3.30, p<0.05)$ and the students' ability to represent their skills and knowledge in the portfolio $(b=0.46, t=5.67, p<0.05)$.

- In semester 2, the level of satisfaction with the subject was regressed with teaching and learning variables and produced an $R^{2}$ value of 0.76 and a significant ANOVA for residuals $(F=11.37(12,42$, $p<0.05)$. Significant results were produced by how often students used the content and skills from other core subjects in the studio $(b=0.32, t=2.44, p<0.05)$, the availability of the studio space

\begin{tabular}{|c|c|c|c|c|}
\hline \multirow[b]{2}{*}{ Rate the following: } & \multicolumn{2}{|c|}{ Jun 2001} & \multicolumn{2}{|c|}{ Oct 2001} \\
\hline & Mean & SD & Mean & SD \\
\hline My level of satisfaction with this subjects content & 3.16 & 1.00 & 3.30 & 0.80 \\
\hline $\begin{array}{l}\text { My level of satisfaction with my overall course so } \\
\text { far BIMS }\end{array}$ & 3.50 & 0.96 & 3.44 & 0.92 \\
\hline $\begin{array}{l}\text { The chances that I would recommend others to do } \\
\text { this course }\end{array}$ & 3.33 & 1.11 & - & - \\
\hline $\begin{array}{l}\text { I preferred learning in the studio environment as } \\
\text { compared to the standard lecture/tutorial environ- } \\
\text { ment }\end{array}$ & 3.87 & 1.04 & 4.18 & 0.99 \\
\hline $\begin{array}{l}\text { I prefer to work as part of a team/group as com- } \\
\text { pared to individual work }\end{array}$ & 3.48 & 1.09 & 3.34 & 1.18 \\
\hline $\begin{array}{l}\text { The pace of the subject compared to other non-core } \\
\text { subjects was very slow }\end{array}$ & 2.66 & 0.92 & 2.80 & 1.08 \\
\hline
\end{tabular}

Table 5: Students' ratings of the level of satisfaction 
$(b=0.25, t=2.23, p<0.05)$, the students ability to negotiate involvement with team members when working on studio activities $(b=0.27, t=2.10, p<0.05)$, how well the studio activities developed the students' knowledge and skills $(b=0.39, t=3.15, p<0.05)$, and the students ability to represent their knowledge in the portfolio $(b=0.21, t=2.06, p<0.05)$.

\section{Discussion}

Results obtained from the surveys provided insightful data with respect to the learners' perceptions about the studio teaching and learning model as it evolved during the year. Student responses in the openended section of the survey helped explain the statistics presented in the results section of this paper and are used to inform the discussion below. Students were generally positive about their learning experiences in the studio environment however, there were a few areas of concern about aspects of the portfolio assessment and the IT infrastructure provided by the studio model.

\section{The Learning Environment}

At the end of both semesters students' high ratings of the learning environment were strongly supported by their open-ended responses. Typical comments show that the students found the studio an inviting place to study, and the facilities useful to their learning:

- I think that the Studio is a very good place in which to further our skills in both team work and various applications.

- the facilities and atmosphere in Studio 1 is really terrific and relaxing. I love going there to do my work.

It was pleasing for the studio teaching staff to observe that students took their work into other designated learning spaces, such as the Café. As students collaborated more frequently on project work and established networks the Café became a popular place to work. The popularity of the Studio Café and its use as a learning space gave rise to other suggestions for future improvement:

- I think the Studio cafe is a bit too small, because most of the time it is so full, you hardly get any place to sit.

- Studio cafe could be a bit more comfortable... such as having larger tables that we can actually use instead of the circular ones as they do not allow us to put all of the work that we are working on.

However, by the end of the year, general sentiments expressed by the students were that the Studio precinct 'was the best place as a learning place.'

\section{IT tools and infrastructure}

Although students appreciated the working environment, there were a couple of problems highlighted at midyear:

- logging in takes forever, depending on which computer you're on and that's only when you ARE able to login.

- Software kept crashing all the time, login is confusing, limited hardware, not enough machines for everyone.

The second concern was in relation to the many peripheral devices that either were mal-functioning or simply not connected:

- The only thing that I can find that is bad is that the Studio 2 photocopier/printer/scanner has not been functional for most of the semester and as yet is still not functioning. 
Studio Teaching

- Web access to studio software has been difficult from outside the Monash network. When using it from ISP's at home it does not work.

However there were positive comments, students valued the opportunity to borrow equipment, and were annoyed when this service was suspended temporarily in semester 2 .

- The loan facilities available to students is fantastic. The loan of laptops is especially an advantage for students who need a computer.

By the end of the year, although there were still problems with the computer systems, the comments indicated that students were less frustrated by the problems than in semester 1. Some students had suggestions for improvements:

- The discussion area is useless unless lecturers post useful information about the subjects on there.

- Not enough computers for everyone and Studio 2 has no floppy disk drive

\section{Teaching and Learning Philosophy}

The philosophy behind the studio was to provide students with an opportunity to develop strategies to cooperate, collaborate, yet be individual. The integrated curriculum was designed to provide the opportunity for students to use the necessary skills for other core subjects. One of the ways to ensure the curriculum was integrated was to draw on the skills and knowledge of the academics teaching in the other core subjects. However, this did cause some problems for the students in semester 1:

- The studio subject was the only subject I could not really understand its purpose.

- The course material was too broad, but I expect that over the next two years I will be able to gradually focus on my particular area of expertise.

- Multiple teaching was valuable, but at times, I found it a little disconcerting when the changeover occurred mid-session. The incoming lecturer was not entirely up to speed on what was happening during the session and this sometimes caused a disruption in concentration.

At the end of semester 2 the students' comments indicated a deeper understanding of the value of the learning experiences in the studio environment:

- I liked the way the Studio subject incorporated and related the learning areas of other core subjects of the BIMS. This makes it seem that the subjects are not separated but relational and hence, easier to understand and apply skills

Throughout the year, a positive outcome was that this style of teaching, and the group work prescribed, did facilitate collaboration and mutual learning:

- ...what I have learnt in studio has been through some of the class members

- the studio activities and group works really help me a lot in understanding the course better. The tutors are really helpful and they really put so much effort in teaching or explaining ...

\section{Portfolio Assessment}

One of the aims of the studio was to provide students with an environment that would inspire creativity and self managed learning. However, the results shown in Table 3, reiterate common findings of other studies into the assessment of higher education learners through portfolios (Akar, 2001). Results from Akar (2001) in his study of evaluating higher education learners through portfolio assessment show that a number of students found it difficult to self-select items and reveal that students were frustrated in the initial stages of implementation and frequently demanded guidance by the academic in charge. In this study, students also found it difficult to manage the self-selection aspect of their portfolios.

- Portfolio is good but with the self-selected items we should be told what kind of work to hand in. 
Many students did not appreciate the opportunities for creative freedom and believed that having the opportunity to self-select items was an indication of a lack of organization of the subject.

- Tell the students what they should achieve by the end of the subject. Have it more structured

- the layout for the portfolio was not made very clear especially in regards to the group assignments. looking at past portfolios which were very thick, it was hard to produce a portfolio that was even half as thick, maybe there was a little misunderstanding somewhere

Granting students the opportunity to take control of their learning was perceived by them as being achieved by taking away their support structures and providing minimum instruction:

- Being a first year I felt there was too much emphasis on own learning, Ifelt that people would have preferred a helping hand now and then

- It is difficult to do the portfolio because the outline was not given clearly especially for self selected items! There is not guideline how to do the portfolio. It's my first time writing portfolio!

Although many students found the preparation of the portfolio time demanding, the most exciting result was that by the end of semester 1, many students indicated that they had developed more understanding of the learning process:

- It seems to be little work throughout the semester, then a big rush of work at the end. Even though it is meant to be an ongoing thing, no student would actively work on the portfolio throughout the semester.

- For the next portfolio I will manage my time better.

These reflections were particularly pleasing because experience has shown that many students feel uncomfortable displaying thoughts that are deliberate, planful, intentional and goal-directed (Flavell, 1971). These thoughts expressed by students indicate a development of their metacognitive processes. Metacognition has been defined as an "awareness of one's own cognitive processes rather than the content of those processes together with the use of that self-awareness in controlling and improving processes" (Biggs \& Moore, 1993). Other researchers have referred to metacognition as "cognitive strategies" (Paris and Winograd, 1990) and "monitoring cognitive processes" (Flavell, 1979). Researchers and educational practitioners believe these metacognitive processes facilitate learning (Davidson et al., 1994).

By semester 2, students found it easier to decide which items to submit for the self-selected portfolio and appreciated the staggering of the mandatory tasks which helped them feel more organized.

- I know what I am comfortable with in Studio it was easy for me to prepare the portfolio and the presentation. Also I was organized this semester and that helped a lot.

- This semester was much better organized, in first semester the last 2 weeks was so confusing. There was so much to do and very little time left.

These comments provided further evidence of deve lopment of the students' metacognitive processes.

\section{How Satisfied were the Students with the Studio Model?}

Overall students were generally satisfied with the course and preferred learning in this type of environment rather than the standard lecture/tutorial environment. Students expressed a preference towards the studio model because of the practical learning approach:

- IMS1000 has been a good experience when it comes to hands-on work with programming software (ie.VB). Has taught me and exposed me to the potentials of working with such software 
- I like to put things into practice, ahead of learning the theory behind it, so the studio openly provided that opportunity.

By the end of semester 2 there was more agreement amongst the students with regard to preferring the studio model to the traditional teaching method:

- I preferred the learning environment of the studio as it promotes interactivity amongst students which mimic the workforce environment

- I really like the Studio environment as compared to standard/lecture/tute, since it really makes it interesting to attend. Even three hour session fly by just like that

- I started to like BIMS after studying the whole year, and whenever given a chance, I always recommend this course to my friends.

\section{Conclusion}

The findings of this study indicate that students' satisfaction with the studio-based subject can be modeled on various teaching and learning factors. This model became clearer at the end of the year and suggests that factors which influence student satisfaction are: availability of the space, how well students perceive the integration of the subjects, how well the studio activities develop knowledge and skills, how much they need to negotiate involvement with team members, and how well they are able to represent their knowledge and skills in their portfolios.

In general most first year students enjoyed learning in the studio environment. The studio facilitates learners' construction of knowledge by providing them with an environment in which they are encouraged to think, create and integrate. An unexpected finding of the study was the evidence of students developing metacognitive skills. Although, there were concerns raised in semester 1 regarding the portfolio assessment, by the end of the year students found it easier to decide what to submit for the self-select part of the portfolio, and how to organize their portfolio. By the end of the year students also found it easier to represent their level of skills and knowledge in the portfolio, which had a significant impact on their satisfaction of the subject.

The cost of running the studio is more expensive than the traditional approach; however, the School of Information Management and Systems has made a commitment to providing this environment, recognizing the value of the educational experience it provides for the students. It is encouraging, therefore, that this study showed the students recognize and value this experience. This research has highlighted four aspects of learning environments: the physical space, the teaching approach, the assessment method, and the IT facilities provided, that are important to consider when constructing new learning environments. It has shown which aspects of these impact on the students' level of satisfaction with their learning. It is intended that the results presented in this paper will be useful as a guide for other institutions planning to implement a studio-based teaching and learning approach.

An area of future research is to conduct a longitudinal study to obtain an understanding of whether students become more adapted to the studio model as they progress through their course.

\section{Acknowledgements}

The authors wish to acknowledge the researchers that contributed prior studies in this field; David Arnott, Martin Atchison, Peter Jamieson, Kathy Lynch and subsequent authors Andrew Barnden and Chris Gonsalvez, involved in further investigations during the review process of this article. 


\section{References}

Akar, H. (2001). Evaluating higher education learners through portfolio assessment. Proceedings of the Informing Science Conference, Krakow, Poland, 17-22. Retrieved October 2002 from http://ecommerce.lebow.drexel.edu/eli/pdf/AkarEBKEvalu.pdf

Anderson, J. O., \& Bachor, D. G. (1998). A Canadian perspective on portfolio use in student assessment. Assessment in Education: Principles, Policy and Practice, 5 (3), 353-379.

Arnott, D. \& Atchison, M. (1997). Professional Engagement and Information Systems Education: Background, Critique and Directions for the Future. In Proceedings of ISECON'97, The International Information Systems Education Conference (pp. 69-76). Park Ridge, IL: Association for Information Technology Professionals. Orlando, Florida, USA.

Bayer, H. (1975). Bauhaus 1919-1928. New York: The Museum of Modern Art.

Biggs, J. B., \& Moore, P. J. (1993). The Process of Learning. New York: Prentice Hall.

Carbone, A., Campbell, H., Arnott, D., Atchison, M., Foott, D., Schauder, D., \& Jamieson, P. (1999). Studio-based teaching in information technology. Grant from Monash University, Australia.

Carbone, A., Lynch, K., Arnott, D. \& Jamieson, P. (2000). Introducing a studio-based learning environment into information technology. Proceedings of ASET-HERDSA 2000 Conference, Toowoomba.

Carbone, A., Lynch K., \& Jamieson, P. (2001). BIMS Survey, Monash University. Retrieved October 2001 from http://cemm.educ.monash.edu.au/klynch/sims/sifgrant/june01.cfm

Carbone, A., Lynch, K., Barnden, A. \& Gonsalvez, C. (2002a). Students' reactions to a studio-based teaching and learning philosophy in a three year IT degree. Proceedings of the 2002 Annual International Conference of the Higher Education Research and Development Society of Australasia, Edith Cowen University, Joondalup Campus, Perth, Australia, 83-91.

Carbone, A., Lynch, K., Barnden, A. \& Gonsalvez, C. (2002b). Students' reactions to studio-based teaching and learning environment (space, it tools and infrastructure) in the bachelor of information management \& systems. The 6th World Multiconference on Systemics, Cybernetics and Informatics, Orlando, USA.

Davidson, J. E., Deuser, R., \& Sternberg, R. J. (1994). The role of metacognition in problem solving. Metacognition: Knowing about knowing (pp. 207-226). Cambridge, MA: MIT.

Federico, P. A. (1999). Hypermedia environments and adaptive instruction. Computers in Human Behaviour 15 (6), $653-692$.

Flavell, J. H. (1971). First dis cussant's comments: What is memory development the development of? Human Development $14,272-278$.

Flavell, J. H. (1979). Metacognition and cognitive monitoring: A new area of cognitive-developmental inquiry. American Psychologist 34: 906-911.

Flores, G. (2000). The history of the Bauhaus. Retrieved October $2001 \mathrm{from}$ http://people.ucsc.edu/ gflores/bauhaus/b1.html

Jamieson, P., Fisher, K., Gilding, T., Taylor, P., \& Trevitt, C. (2000). Place and space in the design of new learning environments. Higher Education Research \& Development 19 (2): 221-236.

Lynch, K. (2001). IT infrastructure for an undergraduate studio-based IT degree. Proceedings of the Twelfth Australasian Conference on Information Systems, Coffs Harbour, Australia, 403-408.

Moran, E. Q., \& Robinson, F. T. (1994). Project portfolio assessment. Education, 115 (1), 51-56.

Shoemaker, B. (1989). Integrative education: A Curriculum for the twenty-first century. Oregon School Study Council Bulletin, 33(2)

Whitford, F. (1992). The Bauhaus: Masters and students by themselves. London: Conran Octopus. 


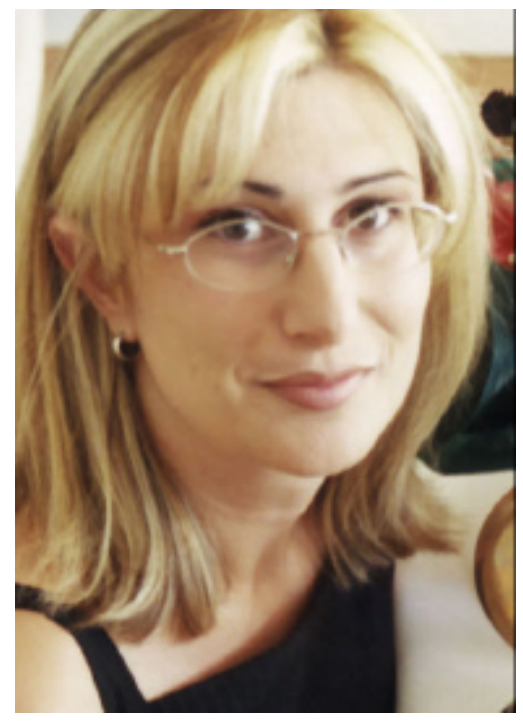

\section{Biographies}

Angela Carbone is a Senior Lecturer in the School of Information Management and Systems, in the Faculty of Information Technology, at Monash University. Prior to that, she held a one-year Professorship in recognition for receiving the Prime Minister's Award for University Teacher of the Year in 1998. Other achievements have included the Vice Chancellor's Award for Distinguished Teaching (1997), the Australian Award for University Teaching in the category of Computing and Information Services (1998) and a finalist of the 2000 Awards for Outstanding Women in Non-Traditional Areas of Work or Study. Currently, Angela is leading a project to develop and implement a studio-based approach to teaching IT. This project was piloted in all year levels of the Bachelor of Information Management and Systems (BIMS) at Monash University. The introduction of the studio has required a radical rethinking of all elements of the teaching program. Her research to date has been published in Australian and international conference proceedings. In 1998 and 1999 Angela was awarded the UNESCO International Centre for Engineering Education, Diamond Award (First Place) for a distinguished contribution, in delivering outstanding papers.

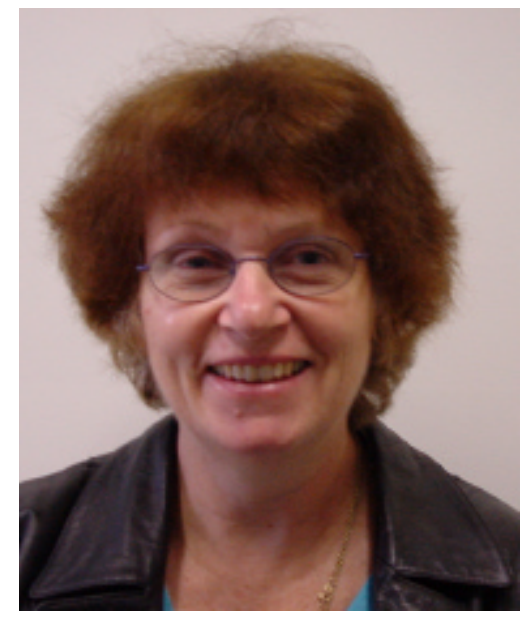

Judy Sheard is a Senior Lecturer in the School of Computer Science and Software Engineering, in the Faculty of Information Technology, at Monash University, Australia. Judy was Program Chair for the $4^{\text {th }}$ Australasian Computing Education conference held in Melbourne, Australia, in 2000 and a co-organiser of the 7th Women in Computing forum held in Melbourne, Australia, in 2000. Judy teaches programming to all levels of undergraduate and graduate level students. She was awarded the Monash Vice Chancellor's award for Team-based Educational Development in 2001 and received a special commendation for the same award in 2000. She received School of Computer Science and Software Engineering Innovation Excellence awards in 2000 and 2001. Judy's main research is investigating issues around the Web as a new educational medium. She is currently examining student interactions with Websites with the intention of developing an intelligent agent and establishing a theory for its use in educational systems. Another area of interest is student learning beha viour, in particular cheating beha viour of tertiary students. She is currently working on a project which aims to determine the extent of cheating behaviour and develop strategies to discourage these practices. 